\title{
Energy Utilization of By-Products from the Soybean Oil Industry by Broiler Chickens: Acidulated Soapstock, Lecithin, Glycerol and Their Mixture
}

\section{-Author(s)}

\section{Peña JEM}

Vieira SL'

Borsatti L

Pontin $\mathrm{C}^{\prime}$

Rios HV

Departamento de Zootecnia, Universidade Federal do Rio Grande do Sul, Porto Alegre, Rio Grande do Sul, Brazil, 91540-000

\section{Mail Address}

Corresponding author e-mail address

S.L. Vieira

Departamento de Zootecnia,

Universidade Federal do Rio Grande do Sul,

Porto Alegre, Rio Grande do Sul, Brasil,

91540-000; Scientific Section: Metabolism and Nutrition

Phone/ Fax: +555133086048

E-mail: slvieira@ufrgs.br

\section{-Keywords}

Acidulated soapstock, broiler, glycerol, and lecithin.

\section{ABSTRACT}

Acidulated soy soapstock (ASS) and lecithin (LEC) are by-products from processing soy oil (SO) for human consumption, whereas glycerol (GLY) can be obtained through the transesterification of vegetable oils during the production of biodiesel. These are valuable by-products for poultry feeds that have been underutilized in many parts of the world. One study was conducted to estimate the $\mathrm{AME}_{\mathrm{n}}$ of ASS, LEC, GLY as well as of their mixture (MIX: $85 \%$ ASS, 5\% LEC and 10\% GLY). Two hundred and sixty Cobb 500 female broilers of 20 days of age were housed in steel wire battery cages in a controlled temperature room for broilers. A completely randomized (energy sources $x$ fat inclusion level) factorial design was applied, with 4 replicates of three birds per treatment. Birds were fed a corn-soybean meal control diet without supplemental fat or with the addition of 2,4 , or $6 \%$ of the four energy sources. Total excreta collection was performed from 26 to 28 days. The $\mathrm{AME}_{n}$ values of by-products were calculated using regression analysis as well as by the difference method. The average $\mathrm{AME}_{n}$ values calculated by regression analysis were: 9,232, 7,502, 5,447 and 8,404, whereas results with the difference method were: $7,951,6,579,3,979$ and $8,101 \mathrm{kcal} / \mathrm{kg}$ for, in both cases for ASS, LEC, GLY and MIX, respectively. It is concluded that these energy sources can be for broilers and that there are significant differences between the methods used to estimate $\mathrm{AME}_{\mathrm{n}}$ of fats.

\section{INTRODUCTION}

Several by-products are obtained during the processing of soy oil (SO) for human consumption, as well as through its transesterification required for biodiesel production. By-products from these processes are generally cheap and are sometimes used in poultry feeds and include lecithin (LEC), acidulated soy soapstock (ASS), and glycerol (GLY).

Lecithin is removed by centrifuging crude soy oil, representing around 1.5 to $3.1 \%$ of the original source (Overland et al., 1994). As for its use by the animal, LEC has important roles in the phosphate and energy metabolism, in addition of being an important source of choline (Menten et al., 1997; Woerfel et al., 1981).

In most markets, SO needs to be previously neutralized before being sold for human consumption. This neutralization entails a chemical reaction with alkali, and as a result, around $6 \%$ of the original fat is a mixture of free fatty acids and mono and diglycerides (Vieira et al., 2002). Values of $A M E_{n}$ of ASS for poultry vary with their oil of origin (Pardio et al., 2001; Vieira et al., 2002; Machado et al., 2003). Important amounts of tocopherols can also be found in ASS (Pardio et al., 2001). 
Glycerol is a by-product of biodiesel production, and each litter of biodiesel yields obtained as around $79 \mathrm{~g}$ of GLY (Min et al., 2010). As a precursor of glyceraldehyde 3-phosphate, GLY produces energy through the glycolytic and tricarboxylic-acid pathways in animals and, therefore, it can also be used as an energy source in poultry diets. Studies have been reported varying $A M E_{n}$ values for poultry (Nelson \& Cox, 2002).

Despite the increasing availability of the by-products of SO processing and biodiesel production, their use in poultry nutrition is still limited. There are few literature reports on their $A M E_{n}$ values, especially when more than one of these by-product are added to poultry diets. Synergistic effects in energy utilization by broilers have been shown when GLY and ASS simultaneosuly are added into the same feed (Sklan, 1979). However, it is less common to add the three mentioned byproducts simultaneously in a same poultry feed.

The objective of this study was to determine the apparent metabolizable energy $\left(\mathrm{AME}_{n}\right)$ values of $\mathrm{LEC}$, ASS and GLY, as well as their mixture in a proportion that resembles their individual proportion in the original crude soy oil (Nelson \& Cox, 2002; Overland et al., 1994; Vieira et al., 2002).

\section{MATERIALS AND METHODS}

All procedures of this study were approved by the Ethics and Research Committee of Universidade Federal do Rio Grande do Sul, Brazil.

\section{Bird husbandry}

A total of two hundred and sixty day-old Cobb $X$ Cobb 500 slow-feathering female broiler chicks, vaccinated for Marek's disease, were obtained from a local hatchery (Frangosul S.A., Montenegro, Brazil).

Chicks were housed on day 1 on floor pens, where they remained until 20 days old. On day 21, birds were randomly allocated into 52 steel battery cages $(0.40$ $\mathrm{m} \times 0.90 \mathrm{~m}$, five birds per cage) equipped with one feeder and one drinker each. Room temperature was controlled to maintain bird comfort throughout the study. Lighting was continuous and feed and water were supplied ad libitum.

\section{Experimental diets}

A basal corn-soybean meal diet without fat supplementation was formulated (Table 1) as well as twelve other treatments diets consisting of the inclusion of LEC, ASS and GLY individually or as their respective combination (MIX: 5\%, 85\% and 10\%, respectively
LEC, ASS and LEC) in the basal diet. Fat sources were added to the feeds at the ratios of 2, 4 and $6 \%$ at the expense of the entire basal feed.

Birds were distributed in a completely randomized factorial arrangement of four energy sources and three levels of inclusion, totaling four replicates of five birds per treatment.

Table 1 - Basal diet composition.

\begin{tabular}{|c|c|}
\hline Item & Basal diet \\
\hline \multicolumn{2}{|l|}{ Ingredients (\%) } \\
\hline Corn & 61.15 \\
\hline Soybean meal & 35.09 \\
\hline Limestone & 0.92 \\
\hline Dicalcium phosphate & 1.79 \\
\hline Salt & 0.48 \\
\hline L-Lysine HCL & 0.11 \\
\hline DL-Methionine & 0.25 \\
\hline Choline chloride $60 \%$ & 0.05 \\
\hline Vitamin and Mineral premix ${ }^{1}$ & 0.16 \\
\hline \multicolumn{2}{|c|}{ Calculated nutrient composition (\% or as noted) } \\
\hline $\mathrm{AME}_{n}{ }^{3},(\mathrm{kcal} / \mathrm{kg})$ & 2876.00 \\
\hline Crude protein & 21.00 \\
\hline Calcium & 0.90 \\
\hline Available phosphorus & 0.45 \\
\hline Sodium & 0.21 \\
\hline $\mathrm{DEB}(\mathrm{mEq} / \mathrm{kg})^{3}$ & 210.00 \\
\hline Choline & 1650.00 \\
\hline Digestible Lysine & 1.10 \\
\hline Digestible total sulfur amino acids & 0.82 \\
\hline Digestible threonine & 0.69 \\
\hline Digestible valine & 0.88 \\
\hline Digestible isoleucine & 0.81 \\
\hline Digestible arginine & 1.31 \\
\hline Digestible tryptophan & 0.22 \\
\hline \multicolumn{2}{|c|}{$\begin{array}{l}\text { 'Supplied per kg of feed: vitamin A: } 8000 \mathrm{IU} \text {; vitamin } \mathrm{D}_{3}: 2000 \mathrm{IU} \text {; vitamin E: } 30 \mathrm{IU} \text {; } \\
\text { vitamin } \mathrm{K}_{3} \text { : } 2 \mathrm{mg} \text {; thiamine: } 2 \mathrm{mg} \text {; riboflavin: } 6 \mathrm{mg} \text {; pyridoxine: } 2.5 \mathrm{mg} \text {; vitamin } \mathrm{B}_{12} \text { : } \\
0.012 \mathrm{mg} \text {; pantothenic acid: } 15 \mathrm{mg} \text {; niacin: } 35 \mathrm{mg} \text {; folacin: } 1 \mathrm{mg} \text {; biotin: } 0.08 \mathrm{mg} \text {; Fe: } \\
40 \mathrm{mg} ; \mathrm{Zn}: 80 \mathrm{mg} ; \mathrm{Mn}: 80 \mathrm{mg} \text {; Cu: } 10 \mathrm{mg} \text {; I:0.7 mg; Se: } 0.3 \mathrm{mg} \text {; monensin sodium } \\
\text { (CobanTM } 40 \% \text {, Elanco Animal Health): } 275 \mathrm{mg} \text {. } \\
{ }^{2} \mathrm{AME} \text { : apparent metabolizable energy corrected for retained nitrogen } \\
{ }^{3} \text { DEB: Dietary electrolyte balance }\end{array}$} \\
\hline
\end{tabular}

The ASS and LEC used in this study were obtained from the Energy Solutions for Animal Nutrition - ESAN (Londrina, PR, Brazil), whereas GLY (99\%) was obtained from INAQUIM Indústria e Comercio Ltda. (Canoas, RS, Brazil). All fat sources were analyzed prior to the beginning of the study according to the methods of the AOAC $(1995,2005,2000)$ and to ASTM (2006) and are detailed in Table 2. 
Table 2 - Chemical characterization of the energy sources utilized to determine apparent metabolizable energy corrected for retained nitrogen (AMEn) values, \% or as noted.

\begin{tabular}{lcccc}
\hline Analysis & ASS $^{1}$ & LEC $^{2}$ & GLY & Analytical method \\
\hline Moisture Karl Fischer & 0.53 & 0.23 & 0.17 & AOAC 984.20 \\
\hline Moisture and volatiles & 1.06 & 5.28 & 0.90 & AOAC 926.12 \\
\hline Crude Protein & 0.12 & 3.42 & 0.00 & AOAC 990.03 \\
\hline Ether Extract & 99.90 & 99.94 & 0.41 & AOAC 920.39 \\
\hline Peroxide value, mEq/kg fat) & 0.00 & 0.00 & 0.00 & AOAC 965.33 \\
\hline Acidity in oleic acid & 77.30 & 10.50 & 9.30 & AOAC C 3d-63 \\
\hline lodine value, g/100g & 11.47 & 94.82 & - & AOAC 993.20 \\
\hline pH aqueous solution & 2.90 & 3.70 & 6.90 & AOCS G 7-56 \\
\hline Ash & 1.27 & 8.09 & 0.03 & AOAC 942.05 \\
\hline Phosphorus & 0.03 & 1.93 & - & AOAC 956.01 \\
\hline Sodium & 0.003 & 0.021 & 0.280 & AOAC 956.01 \\
\hline Glycerol & - & - & 99.20 & ASTM 2006 \\
\hline Methanol, mg/L & - & - & 9.50 & AOAC 958.04 \\
\hline Gross energy, (kcal/g) & 9.14 & 7.78 & 4.30 & Calorimeter \\
\hline
\end{tabular}

${ }^{1}$ Acidulated soapstock

2Lecithin soybean

${ }^{3}$ Glycerol 99\%

\section{Excreta Collection}

Birds had five days of adaptation to the experimental diets. Starting on day 25, total excreta were collected for $72 \mathrm{~h}$, and then homogenized, weighed, and frozen $\left(-18^{\circ} \mathrm{C}\right)$. Feed intake was calculated as the difference between the amounts of feed offered and left in the feeders at the end of the study. Calorimetry was performed using representative samples of the feeds and the excreta that were previously dried at $60^{\circ} \mathrm{C}$ for $72 \mathrm{~h}$ using standard methods (AOAC, 1990).

The energy of the by-products was estimated by two methods: by regression analysis, where $\mathrm{AME}_{n}$ intake was regressed against feed intake with the slope representing the $\mathrm{AME}_{n}$ content of the by-products, adapting the procedure of Dozier et al. (2008), and by the difference method according to the equation of Campbell et al. (1983):

$\mathrm{AME}_{\mathrm{n}} \mathrm{l}=\mathrm{GEI}-\left(\mathrm{EO}_{\mathrm{T}}-(1-X) \mathrm{EO}_{\mathrm{R}}\right) / X$

Where: $(\mathrm{GEI}=$ Gross energy of the test ingredient, $\mathrm{EO}_{\mathrm{T}}=$ Energy output test diet, $\mathrm{EO}_{\mathrm{R}}=$ Energy output reference diet, $X=\%$ Inclusion).

\section{STATISTICAL ANALYSIS}

Data were analyzed using the ANOVA procedure of SAS (2001). The Tukey's HSD test (Tukey, 1991) was applied to determine differences among means, considering a significance level at 5\%. The PROC REG procedure of SAS (Statistical Analysis System, version 9.2) was used for regression analysis, which was conducted for each energy source, considering the basal diet without supplemental fat and the three levels of each added fat source.

\section{RESULTS AND DISCUSSION}

Average $A M E_{n}$ levels of the diets and by-products are presented in Table 3, and average values for each fat source are shown in Table 4. No interaction between fat source and level ( $p>0.05)$ was observed. However, fat level had a significant effect on $\mathrm{AME}_{n}$ content of diets and fat sources $(p<0.01)$, whereas $\mathrm{AME}_{n}$ content of supplemental fat was significantly affected only by fat sources $(p<0.01)$.

Average $A M E_{n}$ values of the fat sources calculated using regression analysis were 9232, 7502, 5447, and 8404 , whereas the values obtained using the difference method were 7951, 6579, 3979, and $8101 \mathrm{kcal} / \mathrm{kg}$ for ASS, LEC, GLY and MIX, respectively (Table 3 ).

The addition of the soybean fat by-products in the present study led to a concurrent increase in $\mathrm{AME}_{\mathrm{n}}$ of diets. This increase was associated with the level of inclusion and with the energy content of each fat source. However, the $\mathrm{AME}_{n}$ values estimated using regression analysis were higher than those calculated using the difference method. The difference method (Campbel et al., 1983) was originally proposed to generate $\mathrm{AME}_{n}$ values using a single level of fat supplementation. According to Wiseman and Salvador and Dozier et al. (1991, 2008), one of the advantages of using multiple fat inclusion levels when determining AME content of fats is that the method does not depend on the individual rates of inclusion of the evaluated fats, thereby reducing the uncertainty of the dietary energy values. Furthermore, the use of multiple inclusion levels allows assessing the effects of inclusion rates. Lower standard errors energy values of the fats investigated are expected when regression equations are applied. In contrast, when low levels of fat are included, such as when the difference method is used, the likelihood of underestimating the $\mathrm{AME}_{n}$ values of the ingredient being studied increases. Depending on the energy source and of its dietary inclusion levels, the response in terms of energy contribution to the animal may be linear, curvilinear, or exceed its gross energy content (Sibbald and Kramer, 1978). Therefore, the methodology proposed by Campbell et al. (1983) may 
be more suitable for the calculation of $\mathrm{AME}_{n}$ contents when fat sources are added at low levels to a reference diet, allowing reducing the negative effects of possible procedure errors made during laboratory analyses.

The two methods applied in the present study, yielded different $A M E_{n}$ estimates of the evaluated fat sources. The obtained values also show some discrepancies when compared with published data. For instance, Gaiotto et al. (2000) reported $6715 \mathrm{kcal} /$ $\mathrm{kg}$ for ASS fed to 5- to 6-d-old broilers, whereas Vieira et al. (2002) and Raber et al. (2008) found ASS energy values of 8115 and $8477 \mathrm{kcal} / \mathrm{kg}$ for 28 and 31-d-old broilers, respectively. These differences may be attributed to the age of birds because the physiological capacity of fat utilization is still poorly developed in young birds; an increase in the fat utilization as birds age are, however, expected (Wiseman \& Salvador, 1989; Blanch et al., 1995; Sakomura et al., 2004). Moreover, determination methods may also affect $A M E_{n}$ estimates. For instance, most of the recent $A M E_{n}$ determinations for ASS were performed using a single inclusion level of this fat source (Gaiotto et. al., 2000; Vieira et al., 2002; Raber et al., 2008).

The NRC (1994) and Rostagno et al. (2011) reported $\mathrm{AME}_{\mathrm{n}}$ of 6440 and $6036 \mathrm{kcal} / \mathrm{kg}$ for LEC, respectively. The commercial availability of LEC is sometimes limited, but this may be a valuable feed ingredient depending on its market price. In addition to its utilization as an energy source in poultry diets, supplementing LEC in poultry feeds also supplies important amounts of choline (14800 ppm as determined by the authors) and phosphorus, as shown in Table 2 .

In the present study, the $\mathrm{AME}_{\mathrm{n}}$ content of GLY was estimated as 5447 and $3979 \mathrm{kcal} / \mathrm{kg}$ by the difference method and by linear regression, respectively. Similar values were obtained by Cerrate et al. (2006) using a single inclusion level, and by Dozier et al. (2008) using linear regression, who determined $\mathrm{AME}_{n}$ values of 3596 $\mathrm{kcal} / \mathrm{kg}$ for 17 - to 24 -d-old broilers and $3434 \mathrm{kcal} / \mathrm{kg}$ for 38- to 45-d-old broilers, respectively. Lammers et al. (2008) reported an $\mathrm{AME}_{\mathrm{n}}$ value of $3805 \mathrm{kcal} / \mathrm{kg}$ for laying hens when replacing GLY for glucose.

The estimated $\mathrm{AME}_{n}$ value of the MIX was higher compared with sum of the values of each individual by-product. Values of 8101 and $8404 \mathrm{kcal} / \mathrm{kg}$ were determined for the MIX using the difference method and linear regression, respectively. In comparison, the sum of $\mathrm{AME}_{\mathrm{n}}$ individual values estimated for each fat source was 7485 and 8767 using both methods. Data reported by Sklan (1979) suggest that the use of combinations of fat by-products can be translated
Table 3 - Apparent metabolizable energy corrected for retained nitrogen $\left(A M E_{n}\right)$ of fat sources and diets with inclusion of by-products of soybean oil processing, $\mathrm{kcal} / \mathrm{kg}$.

\begin{tabular}{|c|c|c|c|}
\hline \multirow{2}{*}{\multicolumn{2}{|c|}{ Fat Source }} & \multicolumn{2}{|c|}{$\mathrm{AME}_{n^{\prime}} \mathrm{kcal} / \mathrm{kg}$} \\
\hline & & $\operatorname{Diet}^{5}$ & Fat source ${ }^{6}$ \\
\hline \multicolumn{2}{|l|}{ ASS $^{1}$} & $3277^{a}$ & $7951^{\mathrm{ab}}$ \\
\hline \multicolumn{2}{|l|}{ LEC $^{2}$} & $3175^{b}$ & $6579^{b}$ \\
\hline \multicolumn{2}{|l|}{ GLY3 } & $3074^{c}$ & $3979^{c}$ \\
\hline \multicolumn{2}{|l|}{$\mathrm{MIX}^{4}$} & $3232^{\mathrm{a}}$ & $8101^{a}$ \\
\hline \multicolumn{4}{|l|}{ Level } \\
\hline \multicolumn{2}{|l|}{$2 \%$} & $3121^{c}$ & 6344 \\
\hline \multicolumn{2}{|l|}{$4 \%$} & $3176^{b}$ & 6631 \\
\hline \multicolumn{2}{|l|}{$6 \%$} & $3276^{a}$ & 6923 \\
\hline \multicolumn{4}{|c|}{ Fat source*Level } \\
\hline ASS $^{1}$ & 2 & 3195 & 7849 \\
\hline \multirow{2}{*}{$\begin{array}{l}\text { ASS }^{1} \\
\text { ASS }^{1}\end{array}$} & 4 & 3250 & 7904 \\
\hline & 6 & 3386 & 8075 \\
\hline \multirow{2}{*}{$\frac{L_{E C C^{2}}}{L E C^{2}}$} & 2 & 3102 & 6332 \\
\hline & 4 & 3171 & 6566 \\
\hline \multirow{2}{*}{$\begin{array}{l}L E C^{2} \\
G L Y^{3}\end{array}$} & 6 & 3252 & 6835 \\
\hline & 2 & 3010 & 3507 \\
\hline \multirow{2}{*}{$\begin{array}{l}G L Y^{3} \\
L L Y^{3}\end{array}$} & 4 & 3098 & 3845 \\
\hline & 6 & 3116 & 4465 \\
\hline $\mathrm{MIX}^{4}$ & 2 & 3176 & 7692 \\
\hline \multirow{2}{*}{$\frac{M I X^{4}}{M I X^{4}}$} & 4 & 3185 & 8193 \\
\hline & 6 & 3335 & 8315 \\
\hline \multicolumn{2}{|l|}{ Mean } & 3194 & 6652 \\
\hline \multicolumn{4}{|c|}{ Probability (ANOVA) } \\
\hline \multicolumn{2}{|c|}{ Fat source } & $<0.0001$ & $<0.0001$ \\
\hline \multicolumn{2}{|l|}{ Level } & $<0.0001$ & 0.4396 \\
\hline \multicolumn{2}{|c|}{ Fat source*Level } & 0.1447 & 0.9991 \\
\hline \multicolumn{2}{|l|}{ SEM } & 15.32 & 297.76 \\
\hline
\end{tabular}

-Means within the same column without common letters differ significantly $(p<0.05)$. 'Acidulated soybean soapstock

${ }^{2}$ Lecithin

${ }^{3}$ Glycerol

${ }^{4}$ Mixture containing $85 \%$ ASS, $10 \%$ GLY and $5 \%$ LEC.

${ }^{5} \mathrm{AMEn}=[\mathrm{GEI}-\mathrm{GEE}]-[8.22 \times(\mathrm{NI}-\mathrm{NE})] \div \mathrm{FI} \mathrm{GEI}=$ Gross energy intake, GEE $=$ Gross energy output in the excreta, $\mathrm{NI}=$ nitrogen intake from the diet, $\mathrm{NE}=$ nitrogen output in the excreta, $\mathrm{Fl}=$ feed intake, and $8.73=$ nitrogen correction factor

${ }^{6} \mathrm{AME}_{\mathrm{n}} \mathrm{I}=\mathrm{GEI}-\left(\mathrm{EO}_{\mathrm{T}}-(1-X) \mathrm{EO}_{\mathrm{R}}\right) / X$, where: $\mathrm{GEI}=$ Gross energy of the fat source, $E \mathrm{O}_{\mathrm{T}}=$ Energy output of test diet, $E \mathrm{O}_{\mathrm{R}}=$ Energy output of the reference diet, $X=\%$ inclusion of the fat source.

into higher $\mathrm{AME}_{\mathrm{n}}$ values because of a synergism when the different sources are consumed together by birds. In addition, fats containing different proportions of unsaturated and saturated fatty acids can lead to higher $\mathrm{AME}_{n}$ values (Renner \& Hill, 1960; Wiseman and Lessire, 1987). The capacity of polar solutes to increase the micellar solubility of non-polar solutes, such as longchain fatty acids, has been proposed as the mechanism responsible for this synergism (Freeman, 1984). The results of the present study demonstrate that ASS, LEC, and GLY at the respective proportions of $85 \%, 5 \%$, and $10 \%$, increased the $A M E_{n}$ value finally obtained for broilers using the difference method. As with the 
other fat sources evaluated, values were numerically higher when linear regression was compared with the difference method.

The increasing market value of energy has affected the cost of energy sources for poultry feeds, especially fats. Using methods of $\mathrm{AME}_{n}$ determination that adequately address the factors that impact fat utilization by the birds, such as inclusion rate, allow for more precise feed formulation. The two methods used in the present study present different degrees of complexity for their implementation. The liner regression method captured the impact of increasing fat inclusion rates in the feeds; however, this method clearly overestimated $A_{M E}$ of GLY, because the determined $A M E_{n}$ value was higher than its gross energy value (Table 2).

The higher $\mathrm{AME}_{n}$ value of the MIX when compared with that obtained by the sum of the individual fat sources as determined by the difference method represents a competitive economic alternative to supply energy for broilers because of the large volumes of GLY currently offered in the market. The failure of the two methods to provide numerically closer $\mathrm{AME}_{n}$ values was an outcome limitation from the present study and remains to be clarified.

Table 4 - Average apparent metabolizable energy corrected for retained nitrogen $\left(\mathrm{AME}_{\mathrm{n}}\right)$ of the soybean oil by-products estimated by two methods, $\mathrm{kcal} / \mathrm{kg}$.

\begin{tabular}{lll}
\hline Ingredient & $\mathrm{AME}_{\mathrm{n}^{\prime}} \mathrm{kcal} / \mathrm{kg}$ & \\
\cline { 2 - 3 } & Regression Analysis $^{5}$ & Difference Method $^{6}$ \\
\hline ASS $^{1}$ & 9232 & 7951 \\
\hline LEC $^{2}$ & 7502 & 6579 \\
\hline $\mathrm{GLY}^{3}$ & 5447 & 3979 \\
\hline MIX $^{4}$ & 8404 & 8101 \\
\hline
\end{tabular}

'Acidulated soybean soapstock

${ }^{2}$ Lecithin

${ }^{3}$ Glycerol

${ }^{4}$ Mixture containing $85 \%$ ASS, 10\% GLY and 5\% LEC.

${ }^{5} \mathrm{AME}_{\mathrm{n}}=\mathrm{y}=\mathrm{a}+\mathrm{bx}, \quad$ GLY $Y=24,69 \mathrm{x}+2978\left(\mathrm{p}<0.0001 ; r^{2}=0,77\right)$, ASS $Y=62,21 \mathrm{x}$ $+3013\left(p<0.0001 ; r^{2}=0,88\right), \operatorname{LEC} Y=45,09 x+2993\left(p<0.0001 ; r^{2}=0.86\right), M I X Y=$ $53,99 x+3007\left(p<0.0001 ; r^{2}=0,78\right)$

${ }^{6} \mathrm{AME}_{\mathrm{n}} \mathrm{I}=\mathrm{GEI}-\left(\mathrm{EO}_{\mathrm{T}}-(1-\mathrm{X}) \mathrm{EO}_{\mathrm{p}}\right) / \mathrm{X}$, where: $\mathrm{GEI}=$ Gross energy of the fat source, $E O_{T}=$ Energy output of test diet, $E O_{R}=$ Energy output of the reference diet, $X=\%$ Inclusion of the fat source.

\section{CONCLUSIONS}

The $\mathrm{AME}_{n}$ values of the soybean by-products estimated by regression analysis are 9232, 7502, 5447, and $8404 \mathrm{kcal} / \mathrm{kg}$, whereas values estimated by the difference method are 7951, 6579, 3979, and $8101 \mathrm{kcal} / \mathrm{kg}$ for acidulated soybean soapstock, lecithin, glycerol, and a mixture of these three at the proportions of $85 \%, 5 \%$ and $10 \%$, respectively.

\section{ACKNOWLEDGMENTS}

This research was supported by Fundação de Apoio à Pesquisa do Estado do Rio Grande do Sul (Fapergs). S.L.Vieira is supported by a grant from CNPq.

\section{REFERENCES}

AOAC - Association of Official Analytical Chemists. Official methods of analysis. 15th ed. Arlington; 1990. 1094p.

AOAC - Association of Official Analytical Chemists. Official Methods of Analysis. 16th ed. Arlington; 1995.

AOAC - Association of Official Analytical Chemists. Official methods of analysis. 18th ed. Gaithersburg; 2005.

AOCS - Association of Official Analytical Chemists. Official methods and recommended practices of the american oil chemists society. 3rd ed. Champaign; 1995.

ASTM - Annual Book of American Society for Testing and Materials Standards International. West Conschohocken: Petroleum Products and Lubericants; 2006.

Blanch A, Barroeta AC, Baucells MD, Serrano XP. Utilization of different fats and oils by adult chickens as a source of energy, lipid and fatty acids. Animal Feed Science Technology 1995;61: 335-342.

Campbell GL, Campbell LD, Blair R. Calculation of metabolizable energy for ingredients incorporated at low levels into a reference diet. Poultry Science 1983;62:705-707.

Cerrate SF, Yan Z, Wang Z. Evaluation of glycerin from biodiesel production as a feed ingredient for broilers. International Journal of Poultry Science 2006;5:1001-1007

Dozier WA, Kerr BJ, Corzo A. Apparent metabolizable energy of glycerin for broiler chickens. Poultry Science 2008;87:317-322.

Freeman CP. The digestion absorption and transport of fats non-ruminants. In: Wiseman, J., editor. Fats in animal nutrition. London: Butterworths; 1984. p. $105-122$

Gaiotto JB, Menten JFM, Racanicci AMC, Lafigliola MC. Soybean oil, acidulated soapstock, beef tallow, and mixtures of fat sources in broilers diets. Revista Brasileira de Ciência Avícola 2000; 2:219-227.

Lammers P, Kerr BJ, Honeyman M, Stalder K, et al. Nitrogen-corrected apparent metabolizable energy value of crude glycerol for laying hens. Journal of Animal Science 2008;87:104-107

Machado LP, Vieira SL, Quadros VR. Source, level and age differences in fat utilization by broilers. Poultry Science Annual Meeting 2003;82(supl 1):39.

Menten JFM, Pesti GM, Bakalli RI. A new method for determining the availability of choline in soybean meal. Poultry Science 1997;76:12921297.

Min YN, Yan F, Liu FZ, et al. Glycerin - A new energy source for poultry. International Journal of Poultry Science 2010;9:1- 4

Nelson DL, Cox MM. Fatty Acid Catabolism In: Lehninger AL. Lehninger principles of biochemistry. $3^{a}$ ed. São Paulo; Sarvier; 2002. p. 631-651.

National Research Council. Nutrient Requirements of Poultry. 9th rev ed Washington, DC: National Academy of Sciences; 1994. p. 155. 
Overland M, Mroz Z, Sundstol F. Effect of lecithin on the apparent ileal and overall digestibility of crude fat and fatty acids in pigs. Journal of Animal Science 1994;72:2022-2028.

Pardio VT, Landin LA, Waliszewski KN. The effect of acidified soapstocks on feed conversion and broiler skin pigmentation. Poultry Science 2001;80:1236-1239.

Raber MR, Ribeiro AML, Kessler AM, Arnaiz V, et al. Performance, metabolism and plasma levels of cholesterol and triglycerides in broilers chickens fed with acidulated soybean soap stock and soybean oil. Ciência Rural 2008;38:1730-1736.

Renner R, Hill FW. The utilization of corn oil, lard, and tallow by chicks of various ages. Poultry Science 1960;39:849-854.

Rostagno HS, Albino LFT, Donzele JL, et al. Tabelas brasileiras para aves e suínos: composição de alimentos e exigências nutricionais. $3^{\mathrm{a}}$ ed. Viçosa; UFV; 2011

SAS Institute. User's guide: statistics. Cary, NC; 2001.

Sakomura NK, Del Bianchi M, Pizauro JR. JM, et al. Effect of age on enzyme activity and nutrients digestibility for broilers fed soybean meal and full fat soybean. Revista Sociedade Brasileira de Zootecnia 2004;33:924-935.

Sibbald IR, Kramer JKG. The effect of the basal diet on the true metabolizable energy value of fat. Poultry Science 1978;57:685-691.
Sklan D. Digestion and absorption of lipids in chicks fed triglycerides or free fatty acids: Synthesis of monoglycerides in the intestine. Poultry Science 1979:58:885-889.

Vieira SL, Ribeiro AML, Kessler AM. Energy utilization of broiler feeds formulated with acidulated soybean soapstock. Revista Brasileira de Ciência Avícola 2002;4:127-139.

Wiseman J, Lessire M. Interactions between fats of differing chemical content; Apparent metabolizable energy values and apparent fat availability. British Poultry Science 1987;28:663-676.

Wiseman J, Salvador F. Influence of age, chemical composition and rate of inclusion on the apparent metabolizable energy of fats fed to broiler chicks. Poultry Science 1989:30:653-662.

Wiseman J, Salvador F. Influence of free fatty acid content and degree of saturation on the apparent metabolizable energy value of fats fed to broilers. Poultry Science 1991;70:573-582.

Woerfel JB. Processing and utilization of by-products from soy oil processing. Proceedings of the world conference on soya processing and utilization. Journal of the American Oil Chemist's Society 1981;58:159-165. 